\title{
Bastide-l'Evêque (La) et Villefranche-de-Rouergue
}

\section{(2) OpenEdition \\ Journals}

Édition électronique

URL : http://journals.openedition.org/adlfi/10962

ISSN : 2114-0502

Éditeur

Ministère de la culture

Référence électronique

"Bastide-l'Evêque (La) et Villefranche-de-Rouergue », ADLFI. Archéologie de la France - Informations [En ligne], Midi-Pyrénées, mis en ligne le 01 mars 1997, consulté le 26 avril 2019. URL : http://

journals.openedition.org/adlfi/10962

Ce document a été généré automatiquement le 26 avril 2019

(C) Ministère de la Culture et de la Communication, CNRS 


\section{Bastide-l'Evêque (La) et Villefranche-de-Rouergue}

Date de l'opération : $1990(\mathrm{PA})$

Inventeur(s) : Morasz Jean-Gabriel

1 Une prospection aérienne a été réalisée sur deux sites d'exploitations minières connus en prospection de surface : le Puech de la Beaume à Villefranche-de-Rouergue et le Puech de Vernhe à La Bastide-l'Évêque.

2 Au Puech de la Beaume, bien que les conditions climatiques n'aient pas été très favorables, les anomalies de croissance de végétation ont confirmé la présence d'un ancien puits d'exploitation remblayé et a montré la répartition exacte des travaux de surface et des haldes anciennes dans une zone escarpée et boisée.

3 Au Puech de la Vernhe, les prises de vue obliques ont permis de repérer précisément dans une zone d'exploitation de galène argentifère une zone d'habitat datable par le matériel recueilli, notamment des fragments de coupes carénées de La Graufesenque, du I ${ }^{\mathrm{er}} \mathrm{s}$. de notre ère.

\section{INDEX}

Index chronologique : Antiquité romaine

operation prospections aériennes (PA) 